\title{
FROM THE SEXUAL DIFFERENCE TO SEXUATION
}

Leonardo Danziato

Leonardo Danziato

Universidade

de Fortaleza

(UNIFOR),

Programa de

Pós-Graduação

em Psicologia,

Fortaleza/CE,

Brasil.

\begin{abstract}
The author revisits a route in Lacan's production that is located between the work "The Signification of the Phallus" and the seminar "Encore", to demonstrate the shift that occurs in the field of psychoanalysis, in regard to the location and function of marking the sexual difference in the structural web of the subject's constitution. As the operator of this twist, the author refers to the notion of jouissance and to the sexuation mathemes developed by Lacan, which led to a consideration of sexuatinno longer distinguished solely by the phallus and the "ideal types" of each sex, but by the field of jouissance, there included the feminine jouissance.
\end{abstract}

Keywords: Sexual Difference, sexuation, sexual diversity, jouissance, feminine.

RESUMO: Da diferença sexual à sexuação. O autor revisita um percurso na obra de Lacan que se localiza entre o escrito "A Significação do Falo" e o seminário "Encore", para demonstrar o deslocamento que ocorre no campo da psicanálise, no que tange a localização e a função de balizamento da diferença sexual na trama estrutural da constituição do sujeito. Como operador desta torção o autor se refere a noção de gozo e aos matemas da sexuação desenvolvidos por Lacan, que determinaram uma consideração da sexuação não mais unicamente abalizado pelo falo e pelos "tipos ideais" de cada sexo, mas pelo campo do gozo, onde inclui-se ai, o gozo feminino. Palavras-chave: Diferença sexual; sexuação; diversidade sexual; gozo; feminino.

DOI - http://dx.doi.org/10.1590/S1516-14982016002006 
A series of current clinical and discursive phenomena triggers a discussion on the structural invariants, particularly regarding the position of the phallus and the sexual difference in the subjectivation of the subject affected by the discursive movements of contemporaneity. Several positions and reading proposals of these contemporary phenomena have already been released, but I will not conduct a survey here of these ideas. I'll enclose my considerations to a recent issue regarding the controversy about the social construction of genders and its "disagreements" with the field of psychoanalysis.

I won't develop the main propositions in the study of genders, as this is not the primary objective of this paper, but just to clarify, I will suggest the work of Butler (2003), as a central reference in this field. It seems to me that there is a crucial "misunderstanding" in the meaning of genre, and in the reading that the work of Lacan allowed about sexuation, because, as we will see, from then on, there are no "genders", but only one gender, the phallic, and the other gender, the female.

Even establishing my positions on the debate, I believe that the criticism and questions raised by the gender studies - as well as any other attempts aimed at the field of psychoanalysis - serve as a point of alterity that allows you to renew and reinvent the theory in order to direct the practice. On behalf of this alterity, and as a way to forward the discussions, I would like to propose and demonstrate that two crucial concepts for the psychoanalytic field need to be considered and developed in this discussion; otherwise the argument may lose its accuracy. They are: the field of jouissance and the real dimension of sexual difference.

I'll discuss this debate within the theoretical course of psychoanalysis from Freud's first propositions on the Oedipus Complex and Castration, as well as on sexual differentiation and its centrality in the constitution of the subject, passing by Lacan's re-readings on the signification of the phallus, until we reach a turning point which will allow us a retrospective resignification of these questions, in what concerns the reformulations produced by the location of the real in the center of the structure, especially what I consider a "dismissal" of the Other (A) which operates in the seminar "From an Other to another" (Lacan, 196869/2008), until we reach the formulations about the sexuation mathemes and of the female jouissance in his seminar Encore (Lacan, 1972-73/2010).

\section{FREUD AND THE PROBLEM OF FEMINISM}

If we start from a psychoanalytical concept that claims the "non-naturalness" of the subject and as a consequence of the sex and of the sexual difference, a logical question is opened on how we come to identify ourselves with what Lacan 
(1958/1998) called "ideal type of his sex" (p. 692). If there isn't an instinctual "knowing" that places us on the sharing of the sexes, how do we get to do it, when we do it? How do we constitute an unconscious knowledge that places us in our identificatory condition of man or woman?

Freud had to work to explain how we identify with the sexual roles assigned to us. Since we don't anchor such a feat in Biology, or Anatomy, or not even in Ontology, it would be necessary to constitute an unconscious knowledge about the sexual difference that would allow the subject to be placed in the sharing of the sexes. All his theorization about the "Oedipus complex" and the "Castration Complex" was the way to clarify how the subject is faced with the sexual difference and symbolizes it, placing himself this time on his own, in the sharing of the sexes.

Freud has established his goals, which included sexual differentiation and his delimitation by the phallus, as well as the effects and the targets of what he called a "bisexual disposition" (Freud, 1925/2011, p. 299). In summary we can say that to him three crucial points should be considered when setting this unconscious knowledge about your gender:

1. The position of the subject in front of the "primacy of the phallus", that is, depending on how one goes by the castration complex and by the Oedipus complex, he/she moves towards a male position as keeper of the phallus, or towards a female condition of reception of the phallus;

2. The effects and redirections given to bisexuality that will determine a "choice" of this sex positioning to the subject. It never hurts to observe that the redirections given to bisexuality are not settled by a repression of the opposite sex: the man would repress the woman, and vice versa. There's a process that doesn't go through repression, but through a choice;

3. From these two, a third point is originated bringing the issue of identification. Here a parenthesis is necessary, because we know that for Freud (1921/2011b) the identification does not refer directly to the man or to the woman, since it describes its three types — rescued by Lacan (1961-62/2003) — and that refer to the "identification with the father" (Freud, 1921/2011b, p. 61), to the identification to "a trace of the person-object" (p. 64), and to an identification "through the symptom" (p. 64). Therefore, there is no direct identification to the "ideal type of his sex" (Lacan, 1958/1998, p. 692), but a movement that goes through registration and positioning with the phallus, as well as to destinations marked by bisexuality.

Being a man or a woman would depend, therefore, of a position before the phallus - from the "signification of the phallus" (Lacan, 1958/1998), using a Lacanian way to say it. In his article on "The Infantile Genital Organization", Freud (19232001c) gives the phallus a place of primacy not only for a position- 
ing in front of the sexual difference, but also for the structural functioning of the subject. He establishes in this text the male character of libido, as well as the centrality of the castration complex and of the Oedipus complex in the delimitation of the child's disposition in the sharing of the sexes.

We know how Freud strictly developed his explanation of sexual difference, not giving a chance to the idea of symmetry, nor of an ontological complementarity between sexes (the way taken by Jung, his most beloved disciple). This is already a remarkable point to what interests us. I would like to highlight it because even though he didn't completely uproot himself from of a phallic binarism, I think we should consider that Freud was not unaware of the real dimension of the sexes and the impossibility of a complementarity. If that were the case, he would have overtaken the logic of these "pre-modern cosmologies" (Žižek, 2013, p. 427) where a possible meeting would happen between the sexes: yinyang, light-darkness, anima-animus, etc. Freud says: «We have, after all, long given up any expectation of a neat parallelism between male and female sexual development» (Freud, 1931/2010, p. 373). Refusing Jung, he walks away from the ontological complementarities of these pre-scientific mythologies.

The fact is that, upon this, Freud presents us a crucial problem to the clinic that concerns the impossibility of absolute knowledge about the sexes. Both in this text above quoted, as at the conference on «Femininity» (Freud, 1933/2011), he always leaves open a full definition on the masculine and the feminine. He even criticizes and replaces his analogy between the male and the active and the female and the passive, suggesting the bisexual character in the sexual life of the human being. He states categorically: "Even in the context of the sexual life of the human being you soon realize how unsatisfactory is to make masculine behavior coincide with activity and feminine with passivity" (Freud, 1933/2011, p. 267). So that Freud is not comfortable with these definitions, and endlessly searches for a theoretical resolution to the theme. I believe he didn't find it. Freud opens the question; he knows that the primacy of the phallus is not enough to define the feminine.

The problem is that he realizes that the whole route that he established on the Oedipus complex and the Castration complex, talks about the constitution of the subject - and here it's already in the Lacanian sense - in his phallic, male position. The prominence of the phallic-male in Freud's ideas concerns the subject's active character, regardless of him being a man or a woman. The female is always a posterior position that implies an Oedipal prehistory, a preOedipal phase (Freud, 1931/2010; 1933/2010) that moves the subject from his solely phallic position in childhood. The girl needs to work more in order to find out the lack. 
In the texts "Female sexuality" (Freud, 1931/2010) and at the conference "Femininity" (Freud, 1933/20103]), we can see Freud struggling with the "impossible" of the feminism, even though incessantly seeking to re-adequate it to the phallic logic. He says: "Psychoanalysis does not try to describe what a woman is - that would be a task it could scarcely perform — but sets about inquiring how she comes into being, how a woman develops out of a child with a bisexual disposition" (Freud, 1933/2010, p. 269). I point out the term "impossible", and remind you that this is a logical category. Even though Freud does not use it this way, it is curious that it appears exactly at this point about the feminine.

But the fact is that before the feminine, Freud struggled with the phallus and its primacy, so that his big hurdle and limit sought a resolution still in the phallic field, even though he knew about this impossibility. However, even risking a possible historic mistake that would be to see in the work of Freud formulations that would not be there, I must admit that three propositions are for me, at the same time, problematic and enlightening, because they indicate that Freud was already dealing with this "real impossibility" of significance of the sexual difference.

A first problematization I consider basic to the others and it concerns this intriguing statement that there is no male and female psychic registration. What does that mean? I would like to suggest some clarifications, which won't be exhausting, but that are good to encourage the debate. For Freud (1915/2010) the drive is neither a man nor a woman, it can be at most satisfied by an active or a passive way. He says: "There is only one libido, which serves both the masculine and the feminine sexual functions. To itself we cannot assign any sex" (Freud, 1933/2010b, p. 289, [emphasis added]). Even the passive route is not enough to say about the feminism, since there is a drive activity in this passive satisfaction. Therefore, it is not the drive character of the body that "teaches" us to be a man or a woman. The headless drive doesn't know, neither wants to know it, since it doesn't even know about itself. It is necessary to consider that there is some importance - a bedeutung — for the drive.

A second aspect, as I have already indicated, refers to his refusal to the complementarity between the sexes, which presents itself in the form of a non-acceptance to an Oedipal symmetry suggested by Jung. Against this idea he proposes a prehistory to the woman, a pre-oedipal phase that would explain the differentiated feminine position regarding the phallus (Freud, 1931/2010).

Thedisplacementthatthis pre-oedipal phasedeterminestothewoman, would already indicate another position with the phallus and with the identification. The dramatic event that follows is to find a definition for female identification, that the phallus, the murder and the incorporation of the father don't achieve. Killing and eating the father produces a subject, but not a woman... Freud is 
faced then with a problem of difficult solution, because even considering that the mother would be seen as an identificatory core to the girl, yet she would not be of the same order of a "primary identification" - this being dedicated to the father, since the "Totem and Taboo" (Freud, 1912-13/1974). Furthermore, the hatred directed to the mother in the access to the girl's Oedipus complex (Freud, 1931/2010), had already operated a dismissal of the mother to her "common" condition of a woman like any other. So, through which way would a girl forward her feminine identification? I recall that becoming a mother would not be a solution either, since motherhood is a phallic activity — therefore, masculine - possible to a woman.

A third point concerns that opposition "phallic/castrated". Considering even accepting that risk - that the "castrated" was the meeting point between Freud and the Real. Because from that comes the difficulties with the feminine, since saying that "the women were castrated" as an unconscious infantile sexual theory (Freud, 1908/1976), is also not enough to signify the feminine. It means that the unconscious sexual theory, the unconscious knowledge about the feminine is insufficient (the formula of trimethylamine displayed on Irma's throat already indicated this impossibility of a knowledge about the feminine). There isn't, then, a reasonable "signification" in the unconscious about "what a woman is" (Freud, 1933/2010b, p. 269).

His strange proposition of a lack of awareness of the female genitals also demonstrates the peculiarity of this issue. Commenting on the passage about the castration complex and the primacy of the phallus, he says: "in all this the female genitals never seem to be discovered. (Freud, 1923/2011, p. 175). As a consequence, the apparently binary opposition does not articulate between the man and the woman, but between the masculine (phallic) and the castrated (p. 175). This takes us to understand that a woman doesn't recognize herself as a woman because she has a vagina. The place of the vagina to the woman is not equivalent to the place of the penis to the man, because the bodily space of phallic identification to the woman is exhibited in the body. While for the man the penis is presented as a primordial signifier, for the woman, in the absence of the penis, the signifiers border a countenance in the whole body. I could anticipate with Lacan: because she doesn't have "one", women have "some" (Lacan, 1972-73/2010). The sexual exchange, therefore, is not between the penis and the vagina, but between the penis and the body. For the woman it is the body that is turned into an object in this exchange.

So, as much as we should consent in the face of the criticism addressed to a phallic and sexual binarism in Freud, yet a "less political" consideration is necessary at this point. It is important to take into account that an issue had been opened by the incompleteness of Freud's text that at no time tried to conceal. On 
the contrary, in an absolutely analytical way, he worked with his impossibilities and bequeathed them tothepsychoanalystsand theentirefield of psychoanalysis as an ethical direction for the clinic.

\section{THE BEDEUTUNG OF THE PHALLUS}

It was Lacan who gave a structural character to this position of the phallus, especially in "The Signification of the Phallus" (Lacan, 1958/1998). I'm not going to take long in the extent of this writing, but only point out two aspects which I consider crucial in this text for the purpose I'm concerned about.

The firstrelates to the fact that Lacan (1958/1998) gives the castration complex a location and a central function, a "node function", both in the regulation of its development as in the installation of the subject in an unconscious position, "... without which he could not identify with the ideal type of his sex" (p.692). This means castration takes a centrality and a priority that surpasses even that of the Oedipus complex, which would be understood by Lacan as "Freud's dream" and therefore would deserve to be interpreted (Lacan, 1969-70/1992). What we have here is an inversion of the Freudian Oedipal structural logic. If for Freud, the Oedipus complex was the time for structuring the subject, for Lacan, the Oedipus complex would already be a "fiction" to explain the effects of castration and to connect the real of sex and death. As Harari (2006) remembers, for Lacan, "... the castration is a deprivation (...), it is not a punishment" (p. 46) as Freud suggested. The Oedipus complex wouldn't be more than a mythical construction that would help us defend ourselves from castration.

Castration, then, takes a primary dimension and starts to be conceived as a "deprivation" (Lacan, 1958/1998p. 692), structurally prior to the Oedipus complex, because it exposes the inconsistency of language structure. Deprivation is not a symbolic lack of an imaginary object, but a real lack of a symbolic object (Lacan, 1956-57/1995). That is, it's not that a signifier is lacking to complement knowledge about the sex, but it's because it never existed. Not by chance, it is to the feminine that this deprivation is addressed, meant as a castration of the mother (Lacan, 1958/1998, p. 693). It is, therefore, of the sexualization of this structural deprivation in the form of the feminine, and outraged in a woman's body.

It is this real lack in the symbolic, the true inexistence of this primordial signifier that leaves us without an absolute knowledge on an ontology of the sexes, because there is no essence of the man or of the woman, since "a man and a woman are nothing else but signifiers" (Lacan, 1972-73/2010, p. 99). Here we're back to the problem of the biological non-anchorage, genetics, anatomy, or gender ontology. 
It's exactly at this point that I can introduce the second aspect of this writing which I consider crucial. Because the phallus is exactly the heir of this nonanchorage of the sexes, it is what will determine the possible meanings of the real of the sex, for those who have primarily lost the being. The human condition of a submission to the language makes us lose this "natural ontology", establishing a "passion of the signifier" (Lacan, 1958/1998, p. 695). From now on no need of necessity, nothing of being, but just the hollow, the hiatus as an effect of the signifier, which determines the demand turns around the void of desire (p.698). As well observed by Zizek (2013) the word "passion" here used by Lacan also involves a meaning of via crucis - as the "passion of Christ" - even if it keeps its common sense of rapture. We are kidnapped by the language and fall into a drive and passionate disorder.

Lacan will develop this "fall of the being" from the relationship between the need, demand and desire, because we turn out to be to an Other, to the desire of an Other. For our purposes, it is enough to know that the natural logic of the need is urverdrangnung (primal repression) (Lacan, 1958/1998, p. 697). In this way, losing this being - mythical - prior to language (that never existed), after an urverdrangnung, we have inherited as a parameter of signification the repressed phallus - verdrangnung. That's why the unconscious is structured like a language. (p. 700). So the unconscious knowledge is sexual, since it has as a pattern the "significance" of the phallus. Demand and desire are, then, like the effects of an unconscious mark of the phallus. Lacan says (1958/1998): "The phallus is the privileged signifier of that mark, of that mark where the part of the logos is joined to the coming of desire" (p.699). Therefore, the phallus is presented here as a substitution to the lack of an "essence" of the man. The being, therefore, is committed because it's always in a relationship with the phallus, that is, in a significant relationship with as an unconscious mark of the phallus.

All the knowledge about the sexes, therefore, is phallic; including the knowledge of women. That's why being a man or being a woman in the unconscious implies being the phallus (the woman) or having the phallus (the man) (Lacan, $1958 / 1998$, p 701). But the problem that will guide Lacan in his later developments is formulated from here: because if we have come to the conclusion that we're definitely deprived of a signifier that represents the feminine, and if all the signifiers are distinguished and signified by the phallus - the very structure of language - this means that all signifiers and all the knowledge they produce are in the phallic field and, therefore, in the masculine field. So, in addition for not having a signifier, we have to conclude that there isn't an unconscious knowledge to the feminine either. So that leaves us with the same Freudian questioning "what's a woman?". 
TO SEXUATION...

To conclude this issue - in that this issue can be concluded — Lacan will have to overcome a topology of the surfaces and of the signifier, locating the structure of the language in another position before the jouissance, in a condition of a spelling "device" (Lacan, 1969-70/1992) of jouissance. Only thus this endless hysterical search of a signifier for the feminine could be exceeded. Understanding that there isn't a signifier to the feminine implies in constituting another field of jouissance, this time outside the language. It still implies in crossing

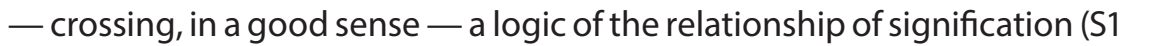
S2), toward an impossibility of this signification, culminating with "there's no sexual relationship" (Lacan, 1972-73/2010).

To proceed with this passage in Lacan's work, we should keep to some crucial points. First important point: Lacan changes his conception of the Other (A). He realizes the inconsistency of the Other, an entropic failure which, paradoxically, makes him move.

In the seminar "From an Other to the other" (Lacan, 1968-69/2008) he will develop an entire elaboration about the "inconsistency of the Other", demonstrating that the "binary pair" (sorry for the redundancy) S1 \S2 never takes place. From the logic observation that "a signifier cannot represent himself" (p. 20), but only one subject to another signifier, he concludes that knowledge about "yourself" becomes an impossibility. This pretense of representation founders in the absence of the other, in the inexistence of this significant other (S2), which solely represents the lack of the other. Logically S2 is the signifier that cannot be contained in the field of the Other. The knowledge of the other, therefore, is inconsistent, because $\mathbf{S} 2$ represents the lack of a signifier in the field of the Other S.

Working with the logic of the "ordered pair" and using Russell's paradox, which states that a set does not contain in itself, Lacan will develop this inconsistency of the Other (A), demonstrating that $S 2$, while the set of signifiers, can always be deployed in S1, S2. So there is a flaw in the knowledge (S2) of the Other (A) (Lacan, 1968-69/2008, p. 58), which is never established in its relation of signification. There's always a remainder as a product of this operation, of which object $a$ is the writing. As Fierens (2012) well summarizes in this passage: "Lacan muestra que el psicoanálisis vá mas allá de uma perspectiva de significación. El decir ya no se aborda por uma relación de significación y su sentido, sino que se aborda por la ausência; el psicoanalista actúa a partir de este vacío, de esa vacuola que podemos ya llamar de objeto a" (p. 81).

Thereafter Lacan develops this reduction of the Other, as a symbolic dimension, to its discursive function without words. The Other $(A)$ which was placed in the symbolic field as a language structure that ex-ists to the subject in the form 
of a discourse and of a desire of the Other, hereafter shall be designed in its alterity with the language: stops being an Other of the language, and becomes another to the language - as opposed to ...

It means that what we have here is a demonstration that the signifier binary logic, as a representative of a relationship of signification, a fall outpaced by finding a logical impossibility of a universe of the discourse: $\mathrm{S} 1$ never reaches S2: S1, S1, S1 ....

A second point is that, precisely because of this reduction of the Other to the other, the notion of language starts to be considered in its function of spelling, of the writing of the jouissance of the body. If the signifier function of the phallus was to distinguish the meanings and anchor the being - as suggested in "The Signification of the Phallus" (Lacan, 1958/1998) - the function of the letter, in turn, is to "write" the real, in its limiting function. The language and its primordial signifiers - S1, S2, the Name-Of-The-Father, the phallus - becomes an "apparatus of jouissance" (Lacan, 1969-70/1992) which seeks the slightest writing of the jouissance of the body. Without this writing, the body would go crazy in an enjoyable and instinctual convulsion, deadly for the subject.

Taking the logic as a model of the language reduction to a writing of the Real, Lacan tries exactly to set aside the signification because he understands that with the Real one can only "write it". This logicization of the language takes him to produce the four discourses (Lacan, 1969-70/1992). He withdraws from the mathematical logic exactly the idea of "literalizing" the real. That is, if the real can't be symbolized at all, it can, however, be demonstrated, as in math, through the logic writing. If the logic fails to establish a "metalanguage", at least it allows the possibility of a "de-monstration".

Crossing the relationship of signification among the binary signifiers, and setting the language in its function of writing - as a "saying" -, Lacan determines another "substantial" field for the subject, the field of jouissance (Lacan, 1969-701992). If there is a substance from where the subject could be placed in his relationship with the real of the sex, it wouldn't be another rather than an "enjoyable substance ". In this other field in relation to language that will place what could be said about sexuation.

As I said, what the quantum formulas of sexuation (Lacan, 1972-732010) operate is this crucial displacement from the phallic field to the field of jouissance. These twists in his work demonstrated the inadequacy of the phallus signification in the spelling of the jouissance of the body. As much as the phallus continues as a central goal for the subject, the space of signification widens to the field of jouissance. If the phallus was the privileged heir of this original deprivation that made us lose the anchorage of the "being" — being a man or a woman - now this lost "being" returns to Lacan, in the form of a "jouissance 
of being" a jouissance in the Real, impossible to be written by language (Lacan, 1972-73/2010, p. 115).

Observe that the being changes his status, as it is no longer a "lost nature", a natural loss as a language effect, but a Real dimension that is not in the old nature prior to the language, but as a jouissance pertaining to the structure. This is what enables Lacan (1972-73/2010), at the seminar "Encore" to refer to an "enjoyablesubstance", as the spacewherethesignification should also beconsidered. What is established here is another relationship between knowledge, truth and jouissance, as well as another signifier's position in its relationship with the real.

It opens then the possibility of considering a jouissance off the phallic field. If not everything belongs to the signifier's field, so a jouissance out of the language remains in the real rawness of "being". This opening finally causes the possibility that one can talk about the feminine in a way that is not from the phallic, but as a jouissance outside-the-phallic.

The sexual difference, therefore, gains another dimension, no longer linked to the identification with the ideal type, but to a possible spelling of jouissance. So that masculine and feminine start to be considered in the Lacanian field of the manifestations of jouissance of the body, and forwarded by the subject from the way it is spelled or not, but always considering that it is a signifiable "not-all" (Lacan, 1972-73/2010, p. 23). Thus, opposed to the phallic-sexual masculine jouissance, is not exactly the woman, but a jouissance outside of language.

The sexual difference starts to be considered, therefore, in its dimension of the Real, in the sense that it is impossible to symbolize. If there is a possible signification of the real of the sex through the phallus and, consequently, a signification of a portion of the jouissance of the body in the sexual field, the other to whom this sexual is directed and opposes, there's no way to represent it. From the quantum formulas of sexuation we see that the subject (\$), from the phallic-sexual field tries to find the other (A), but what he comes across is always an object $a$. Between the subject and the other there is an $a-"$ "... a stone in the middle of the road ...". The tragic side is that this stone is his own body.

Considering the language a jouissance apparatus that handles two impossibilities - the impossibility and the impotence — but that still allows some spelling of the jouissance of the body in the social bond, I can conclude that the "binary" sexual difference is already an attempt to limit in this impossibility of sexual complementarity. As Zizek (2013) says, "... "sexuality" is how the ontological impasse, the incompleteness of reality itself is inscribed into subjectivity" (p. 433). What Lacan means when he says that the sexual difference is real, is that the binary signifier, as we have seen, is always missing. That's why the problem of the sexual difference in Lacan doesn't settle in the issue of the "social construction of genres". The binary opposition that serves both as a critique to 
psychoanalysis on the part of genres, for Lacan, it is never achieved: this is the real problem of sexual difference. I insist with Zizek: "The question is not that the sexual difference is the final signifier of all pairs, but that its proliferation is an attempt to compensate for the lack of the founding signifier's pair that would directly represent the sexual difference" (p. 434). This is because the sexual difference is impossible to symbolize completely, that it requires a sexuation from the subject. If "the sexual relationship does not exist" and in the absence of a binary signifier (S2) that complements this signification, this real of the sex requires the subject to produce a writing of the jouissance of the body.

Therefore, the sexual difference is not a binary opposition socially constituted and lost in "wandering" of the historical and cultural symbolism, but the required writing that every subject when in contact with the field of language, when submitted to language starts to be demanded: spell the jouissance of the body. The sexual difference, then, is what can be written and what makes it impossible in this operation. It is not, therefore, of the symbolic and binary opposition between man and woman, nor of the multiplicities of jouissance that promise multiple identities, since there are not numerous sexualities, not even two.

What we can say is that for Lacan, as Zizek (2013) recalls, after its development on the inconsistency on the other, there is more than one and less than two sexes: there is only $1+a$. The quote "the sexual relationship does not exist" implies a topological relationship with the other, where there is never an encounter: there no knowledge (S2) of the other that can complement the "being" of the subject, as there is no last jouissance — or a first one - that satisfies the craving for a "unification". This impossibility, however, cannot be understood as an "impediment" in the search for the other. On the contrary, it is because it is impossible to find the other, that we create social bonds; it is because the sexual relationship is impossible, that love comes to substitute it (Lacan, 197273/2010). A love directed to what is always making an alterity: the feminine.

Recebido/Received: 8/11/2014. Aprovado/Accepted: 10/6/2015. 


\section{REFERENCES}

Butler, J. (2003). Problemas de gênero. Feminismo e subversão da identidade. Rio de Janeiro, Civilização Brasileira, 2003.

Fierens, C. (2012). Lectura de L'Etourdit. Lacan 1972: sexuación y discursos, el muro de lo imposible. Barcelona, S \& P Ediciones, $421 \mathrm{p}$.

Freud, S. (1908/1976). Sobre as Teorias Sexuais das Crianças. In Edição Standard Brasileira das Obras Completas de Sigmund Freud. Rio de Janeiro Imago, Vol. IX.

Freud, S. (1931/2010). Sobre a Sexualidade Feminina. In. Obras Completas, volume 18: O Mal-Estar na Civilização, Novas Conferências Introdutórias à Psicanálise e outros textos (1930-1936); tradução Paulo César de Souza - São Paulo, Companhia das Letras.

Freud, S. (1933/2010b). Novas Conferências Introdutórias à Psicanálise. Conferência 33. A Feminilidade. In. Obras Completas, volume 18: O Mal-Estar na Civilização, Novas Conferências Introdutórias à Psicanálise e outros textos (1930-1936); tradução Paulo César de Souza - São Paulo, Companhia das Letras.

Freud, S. (1915/2010c). Os Instintos e seus Destinos. in. Obras Completas, volume 12: Introdução ao Narcisismo: ensaios de metapsicologia e outros textos (1914-1916); tradução Paulo César de Souza-São Paulo, Companhia das Letras.

Freud, S. (1925/2011). Algumas Consequências Psíquicas da Diferença Anatômica em ter os Sexos. In. Obras Completas, volume 12: O eu e o id, autobiografia e outros textos; tradução Paulo César de Souza - São Paulo, Companhia das Letras.

Freud, S. (1921/2011b). Psicologia das Massas e Análise do Eu. in. Obras Completas, volume 15: Psicologia das Massas e Análise do Eu e outros textos (1920-1923). tradução Paulo César de Souza - São Paulo, Companhia das Letras.

Freud, S. (1923/2011c). A Organização Genital Infantil. In. Obras Completas, volume 12: O eu e o id, autobiografia e outros textos; tradução Paulo César de Souza - São Paulo, Companhia das Letras.

Freud, S. (1900/2012). A Interpretação dos Sonhos. Porto Alegre, RS: L P\&M, $400 p$.

Harari, R. (2006). Por que não há Relação Sexual? Rio de Janeiro, Companhia de Freud.

Lacan, J. (1958/1998). A Significação do Falo. in Escritos, Rio de Janeiro, Jorge Zahar, $937 \mathrm{p}$.

Lacan, J. (1961-62/2003). A Identificação: seminário 1961-1962. Recife, Centro de Estudos Freudianos do Recife. Publicação não comercial exclusiva para os membros do CEF.

Lacan, J. (1972-73/2010). Encore. Rio de Janeiro, Escola Letra Freudiana, Edição não comercial. Tradução Analúcia Teixeira Ribeiro, 277p.

Lacan, J. (1969-70/1992). O Seminário, livro 17: O Avesso da Psicanálise. Rio de Janeiro, Jorge Zahar.

Lacan, J. (1956-57/1995). O Seminário: livro 4: a relação de objeto. Rio de Janeiro, Jorge Zahar. 
Lacan, J. (1968-69/2008). O Seminário, livro 16: De um Outro ao outro. Rio de Janeiro, Jorge Zahar.

Zizek, S. (2013). Menos que nada: Hegel e a sombra do materialismo dialético. São Paulo, Boitempo, $652 \mathrm{p}$.

Leonardo Danziato

leonardodanziato@unifor.br

Traduzido do português por Doris Dana/translated from portuguese by Doris Dana

dorisdana@uol.com.br 